\title{
Using gut contents to assess foraging patterns of juvenile green turtles Chelonia mydas in the Paranaguá Estuary, Brazil
}

\author{
F. M. Guebert-Bartholo ${ }^{1}$, M. Barletta ${ }^{1,2, *}$, M. F. Costa ${ }^{1,2}$, E. L. A. Monteiro-Filho ${ }^{3,4}$ \\ ${ }^{1}$ Laboratory of Ecology and Management of Estuarine and Aquatic Ecosystems, Department of Oceanography, \\ Federal University of Pernambuco, 50740-550, Recife, Pernambuco, Brazil \\ ${ }^{2}$ Instituto de Ecologia e Gerenciamento de Ecossistemas Aquáticos (IEGEA), PO Box 8132, Recife, Pernambuco, Brazil \\ ${ }^{3}$ Laboratory of Biology and Ecology of Vertebrates, Federal University of Paraná, 81531-970, Curitiba, Paraná, Brazil \\ ${ }^{4}$ IPeC-Instituto de Pesquisas Cananéia, 13098-606, Campinas, São Paulo, Brazil
}

\begin{abstract}
This study investigated use of the Paranaguá Estuary as a foraging habitat by juvenile green turtles Chelonia mydas (L.) by comparing gut contents to available vegetal resources within the estuary. Between June 2004 and July 2007, the carcasses of 80 juvenile green turtles (carapace length range 29 to $73 \mathrm{~cm})$ were found stranded $(n=71)$ or captured $(n=9)$ in fishing nets. The digestive tracts of 76 turtles contained food contents which were quantified (ml) and identified (e.g. algae, seagrass, mangrove propagules, mangrove vegetation and shells). Anthropogenic debris was classified by material, colour and size. Green turtles fed primarily on Halodule wrightii (42.9\% of total volume), other vegetal resources (Ulva spp.: $6.7 \%$; Avicennia shaueriana propagules: $10.1 \%$ ) and other items $(37.9 \%)$; ingested animal matter was seldom recorded $(2.4 \%)$. The occurrence and/or availability of vegetal resources were assessed throughout the year. $H$. wrightii was ingested more frequently during the early rainy season, when the index of importance in the diet was higher (feeding index, FI: 97.3). Ulva spp. was ingested principally in the late dry season and A. shaueriana propagules in the late rainy season (FI: 23.9 and 12, respectively), when $H$. wrightii was not available. Anthropogenic debris was frequently ingested (69.7\% of individuals), and was especially important in the late rainy season (FI: 60.3). This study highlights the importance of sheltered ecosystems such as the Paranaguá Estuary and adjacent regions in providing shelter, feeding grounds and resting areas for juvenile green turtles.
\end{abstract}

KEY WORDS: Feeding $\cdot$ Plastic ingestion $\cdot$ Seasonal changes $\cdot$ Sheltered ecosystems $\cdot$ Green turtle Gut content analysis

Resale or republication not permitted without written consent of the publisher

\section{INTRODUCTION}

The green turtle Chelonia mydas is a marine species that inhabits the tropical and subtropical oceans (Márquez 1990). The species has been catalogued as Endangered on the Red List of the IUCN (2009) since 1982. Green turtles are threatened by human impacts such as incidental capture by fishing activities and boat collisions (Wallace et al. 2010), ingestion of and entanglement in plastic debris (Bjorndal et al. 1994), chemical pollutants (Storelli \& Marcotrigiano 2003) and poaching (Mancini \& Koch 2009). Habitat degradation and loss also pose major threats to green turtles, especially those activities that impact feeding areas, such as maritime operations, dredging and harbour construction (López-Mendilaharsu et al. 2008, Montague 2008).

Green turtles using Brazilian waters for foraging are from mixed stocks, originating primarily from nesting assemblages at Ascension Island, Surinam, Aves Island 
and Trindade Island (Naro-Maciel et al. 2007, Bondioli et al. 2009, Proietti et al. 2009). Migrations from nesting areas to foraging areas, mostly of long geographical distance, are a fundamental characteristic of the species and may be influenced by marine currents acting as a distribution mechanism (Naro-Maciel et al. 2007). In terms of movements, young green turtles show high levels of site fidelity, with home ranges on the order of several kilometres (López-Castro et al. 2010). Large green turtles may have long-range movements $(>100 \mathrm{~km})$ depending on life stage (immature, adult) and diet, depending on whether they are feeding on seagrass or have an omnivorous diet (Godley et al. 2003).

Green turtles utilise different habitats during their life cycle. During the pelagic phase, post-hatchlings and young juveniles develop an opportunistic feeding strategy, preying on planktonic organisms which often aggregate at frontal zones (Bolten 2003). Many juveniles (20 to $35 \mathrm{~cm}$ curved carapace length, CCL) recruit to neritic habitats (e.g. estuaries, coastal areas and coral reefs) where they develop a herbivorous diet based principally on seagrasses and algae (Mortimer 1981), or an omnivorous diet (Bjorndal 1997). Large immature and adult individuals $(>80 \mathrm{~cm})$ are also primarily herbivores, feeding on seagrass and/or algae in many regions including the Arabian Sea (Ferreira et al. 2006), Pacific Ocean (Garnett et al. 1985, Forbes 1996, Amorocho \& Reina 2007, Arthur \& Balazs 2008, Carrión-Cortez et al. 2010), North Atlantic Ocean (Seminoff et al. 2002) and Caribbean Sea (Mortimer 1981).

Studies on Chelonia mydas diet in the southwestern Atlantic have reported a diet dominated by algae for juveniles and adults (CCL 31-120 cm) in northeast Brazil (Ferreira 1968) and juveniles (CCL $30-50 \mathrm{~cm}$ ) in southeast Brazil (Sazima \& Sazima 1985). Juveniles in southern Brazil (CCL $28-50 \mathrm{~cm}$ ) reportedly have an omnivorous diet including animal prey (e.g. fish, molluscs, crustaceans and insects) and vegetation (Ulva spp. and Luziola peruviana, a terrestrial grass species; Bugoni et al. 2003).

Resource availability was not assessed in any of these studies, making it difficult to determine which food resource was preferred. Attempts to correlate resource availability and feeding preferences of juvenile green turtles in other regions indicated that green turtles showed preferences for certain species of seagrasses (Fuentes et al. 2006) and/or algae (LópezMendilaharsu et al. 2008).

The aim of the present study was to assess the diet and feeding patterns of green turtles in an area of the Paranaguá Estuary, Brazil, and adjacent beaches. This was achieved by correlating food resource availability in the environment to occurrence of vegetal resources in samples of turtle gut contents. We conducted this study during both rainy and dry seasons.

\section{MATERIALS AND METHODS}

Study site. The Paranaguá Estuary complex in southern Brazil $\left(25^{\circ} 20^{\prime}\right.$ to $25^{\circ} 35^{\prime} \mathrm{S} ; 48^{\circ} 17^{\prime}$ to $\left.48^{\circ} 42^{\prime} \mathrm{W}\right)$ is approximately $600 \mathrm{~km}^{2}$, encircled by one of the last remnants of Atlantic rainforest (2071.685 ha), and is considered a Natural World Heritage site (UNESCO 2010). The main area is divided by small bays: along the north-south axis are the Laranjeiras, Guaraqueçaba and Pinheiros Bays, and along the east-west axis are the Paranaguá and Antonina Bays.

Extensive mangrove forests, tidal flats, rocky shores and sandy beaches border the estuary (Noernberg et al. 2004). Small patches of seagrass are found in shallows of up to $4 \mathrm{~m}$ depth in the estuarine euhaline sector. Sandy beaches extend for a total of $20 \mathrm{~km}$ towards the north and south from the estuary facing the Atlantic Ocean.

The Paranaguá Estuary and its adjacent areas are used for 4 main human activities: artisanal fishery, port facilities, urban/tourism development (Pierri et al. 2006) and nature conservation. The Guaraqueçaba Bay and its surroundings, including parts of the lower estuary, are better preserved than the east-west axis of the estuarine complex. The bay houses 2 main types of conservation units: restricted use (Superagui National Park) and sustainable use (Environmental Protected Area of Guaraqueçaba; Fig. 1).

Fishing practices are traditional and small scale. They comprise different gears and target species, ranging from simple subsistence practices to more technologically sophisticated forms. Gillnets are frequently used for capturing fish such as Serranidae, Clupeidae and Sciaenidae, and trawl nets are used for shrimp. The fishing grounds are overexploited, and fishing efforts are concentrated in the estuary and continental shelf (Andriguetto-Filho et al. 2009). Sea turtles are frequently captured in gillnets, especially nets with larger mesh size that have drifted for more than $8 \mathrm{~h}$ in the water (Guebert et al. 2005). The estuary is considered a nursery ground for fish species (Barletta et al. 2008, 2010) and is an important feeding and resting site for estuarine dolphins and Franciscana (Sotalia guianensis, Pontoporia blainvillei; Santos et al. 2010).

The Paranaguá Estuary can be divided into 4 main habitats: upper, middle and lower estuary (Barletta et al. 2008) and its adjacent coastal areas (Fig. 1). Seasons were divided according to the rainfall pattern, into early (July, August and September; D1) and late (October, November and December; D2) dry, and early (January, February and March; R1) and late (April, May and June; R2) rainy seasons (Barletta et al. 2008). 


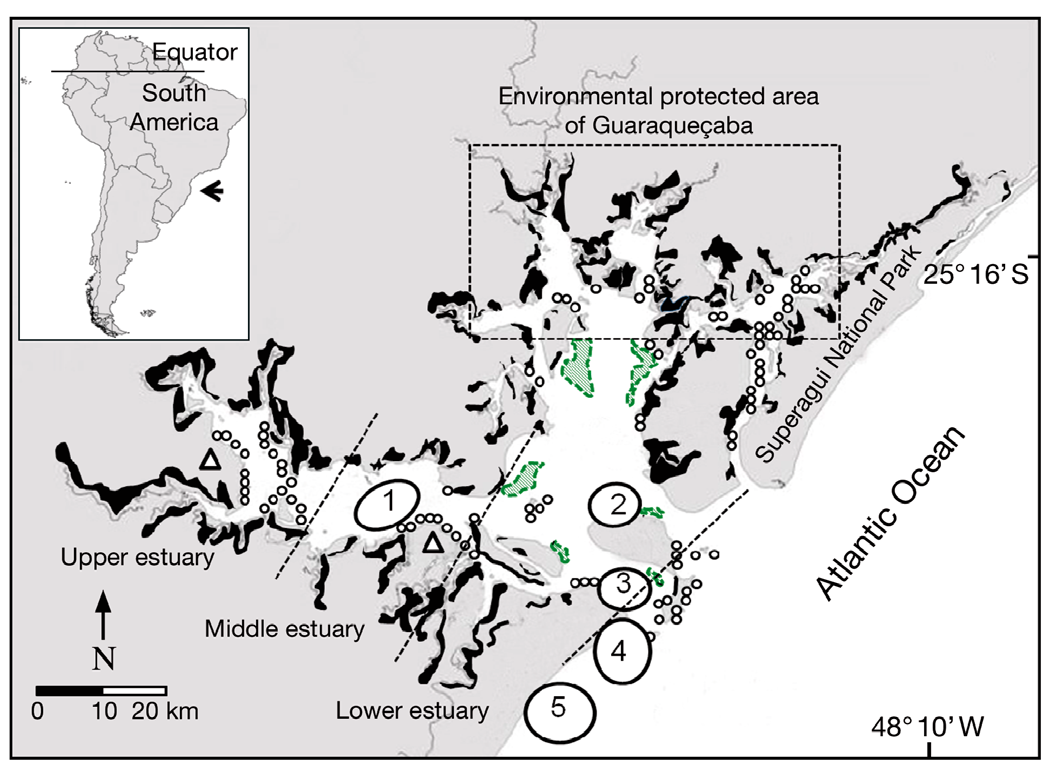

Fig. 1. Paranaguá Estuary. Estimated coverage, distribution, and seasonality of the 3 main food resources that were identified in the gut contents of green turtles Chelonia mydas collected locally: Ulva spp. (O), Avicennia shaueriana, Rhizophora mangle, Laguncularia racemosa (black areas) and Halodule wrightii (green areas). $(\Delta)$ Port facilities. Numbers 1 to 5 indicate the 5 areas where stranded dead turltes were found

The digestive tract (oesophagus, stomach and intestine) was collected and each part was analysed separately. All samples were preserved frozen. Food contents were examined using the volume displacement method (Seminoff et al. 2002, Amorocho \& Reina 2007, López-Mendilaharsu et al. 2008, Carrión-Cortez et al. 2010). Entire sample volume and relative volume of each food item were determined by measuring water displacement in different-sized cylinders, depending on the volume of samples, to obtain the most accurate results possible (to the nearest $2 \mathrm{ml}$; Forbes 1999). The individual items from the gut contents were identified to the lowest possible taxonomic level. Algae and vegetation were identified using taxonomic keys and specialised literature (Joly 1967, de Oliveira et al. 1983). Animal items were identified by comparisons with specimens collected in the region. Anthropogenic debris was classified by material (plastic bag, hard plastic,

Salinity shows a seasonal trend especially in the upper estuary (0 to 16), principally during the late dry season and early rainy season. The middle area has intermediate salinity values, and during the rainy season it is influenced by mesohaline and oligohaline waters. For this environmental variable, the middle estuary showed characteristics closer to the lower estuary, independent of season (Barletta et al. 2008). The lower estuary is dominated by marine waters throughout the year and presents the highest salinity values $(>25)$. Water temperature follows the same seasonal trends throughout the estuary, with the highest temperatures during the rainy season $\left(27\right.$ to $\left.33^{\circ} \mathrm{C}\right)$ and the lowest during the early dry season $\left(10\right.$ to $15^{\circ} \mathrm{C}$; Barletta et al. 2008).

Stranded green turtles were more frequently observed and collected in the lower estuary and adjacent beaches, due to easier access for monitoring efforts. Five areas in which stranded dead turtles were found were analysed (Areas 1 to 5 in Fig. 1).

Survey methods. This study was undertaken between June 2004 and July 2007. Adjacent beaches and the estuary were monitored weekly to collect the stranded dead turtles. A regional fishermen's association agreed to collaborate with our work, and when a turtle was incidentally captured during fishing activities they usually called to have the dead animal taken to the laboratory. All animals collected were measured and CCL was recorded. rubber, nylon and polystyrene), colour (transparent, white and coloured) and area $(<1,1.1-5,5.1-10$, $>10 \mathrm{~cm}^{2}$ ). Area was determined by taking measurements of the 2 largest dimensions of each item (in $\mathrm{cm}$ ). Food contents from the oesophagus and stomach were identifiable and were therefore analysed together. Contents of intestines were either faeces or anthropogenic debris and, in the latter case, were used in the debris analyses only.

Assessing resource availability. Food items (e.g. seagrass, mangrove propagules, algae) that were observed in the gut contents were evaluated as potential food resources through remote sensing. A satellite image of the estuary was used to delimit the area, with surveys conducted at low tide to estimate the total area occupied by each food item. The image analysed was a TM/Landsat acquired in March 2005; it was accurate to $30 \mathrm{~m}$ and was used to determine the coverage of algae and mangrove forests. The vegetation zones in the image were outlined by manual construction of a polygon following the distinct zones (mangrove areas and algae) as closely as possible; the vegetation showed up as dark spots in the composition Red5/Green4/Blue3 due to the difference in soil composition (DahdouhGuebas et al. 1999). The region considered in this analysis was the entire Paranaguá Estuary, based on the assumption that the turtles can utilise the entire estuary. Field work was carried out to ground truth the data in the satellite image in December 2006 (R1), May 
2007 (R2), August 2007 (D1) and October 2007 (D2) in the east-west axis of the Paranaguá Estuary. During these ground truthing efforts, the emphasis was on the rocky shores, mangrove forests and shallow bottoms traced on the remote sensing map. On these occasions, seagrass meadows were observed between 1 and $5 \mathrm{~m}$ depth and delimited by scuba divers and surveys at low tide. Areas where seagrass was detected were divided into transects, measured, recorded with GPS, and then estimated for size $\left(\mathrm{km}^{2}\right)$. In order to investigate temporal variations of their availability, the mangrove and algae resources were described seasonally (D1, D2, R1 and R2) based on studies of their biology, seasonality and occurrence (de Oliveira et al. 1983, Sessegolo \& Lana 1991, Clarke 1993, Creed 1999), taking into consideration the fact that the estuary is a preserved site, and even though a few disturbances occur, these do not affect the seasonal variations of these resources. Previous studies reporting similar approaches and results were compared to verify accuracy (Noernberg et al. 2004, Krug et al. 2007).

Statistical analysis and data presentation. KruskalWallis non-parametric tests were used to detect significant differences in diet (main food items) of stranded turtles versus those caught in fishing gear. The same test was used to detect significant differences in the ingested anthropogenic debris (type, colour and size) and between seasons (D1, D2, R1, R2) and collection areas $(1,2,3,4,5)$. A $5 \%$ level of significance was used. The test was performed using Biostat 5.0.

Three different indices were used to investigate the ingested food contents: frequency by volume (\% FV), frequency of occurrence (\% FO; Hyslop 1980), and feeding index (FI; Kawakami \& Vazzoler 1980).

$$
\mathrm{FV} \%=\left(V_{i} / V_{j}\right) \times 100
$$

where $V_{i}$ is the volume of the food item $i$, and $V_{j}$ is the total volume of all samples.

$$
\mathrm{FO} \%=\left(F_{i} / F_{j}\right) \times 100
$$

where $F_{i}$ is the number of samples containing the food item $i$, and $F_{j}$ is the total number of samples.

To evaluate the relative importance of each food item in the diet, the FI was applied. FI considers that the most frequent food item (FO) does not always have the highest volume (FV). This index gives an indication of the importance of each food item ingested using FO and FV values, for each season of the year, for samples divided by season (D1, D2, R1, R2). The 3 most important food items were determined as follows:

$$
\mathrm{FI}=\left(\mathrm{FO}_{i} \times V_{i}\right) / \sum_{i=1}^{\mathrm{n}} \times\left(\mathrm{FO}_{i} \times V_{i}\right)
$$

where $\mathrm{FO}_{i}$ is the frequency of occurrence of the food item $i(\%), V_{i}$ is the relative volume of food item $i(\%)$, and $\mathrm{n}$ is the number of food items.
Diet similarity among seasons and sampling locations was tested with non-metric multidimensional scaling (MDS) using a Bray-Curtis similarity matrix, performed with PRIMER 6.0 (Clarke \& Warwick 1994) computed with $\log (x+1)$ transformation. A cluster dendrogram was made using the hierarchical group average linking from the food items matrix. This analysis used the 10 most common food items, including all anthropogenic debris, but excluding items that were rarely ingested $(<6 \%$ of total volume).

\section{RESULTS}

\section{Turtles captured}

In total, 80 turtles ranging from 29 to $73 \mathrm{~cm} \mathrm{CCL}$ (mean 49.7, $\mathrm{SD} \pm 7.7$ ) were analysed. Of the 80 juvenile green turtles sampled, 76 had food contents in the oesophagus and stomach. Nine animals had drowned after entanglement in fishing nets. Five of these presented signals of poor health conditions (1 probably from anthropogenic debris ingestion). Of 67 animals found stranded dead on beaches, 3 had died due to the ingestion of anthropogenic debris. The other 64 presented healthy body condition.

\section{Turtle diet in the Paranaguá Estuary}

In total, we measured $5796 \mathrm{ml}$ of ingested items. Seven categories, divided among vegetal $(n=9)$, animal $(n=1)$ and inorganic items $(n=5)$, were identified. No differences were detected in the composition of the total diet of the 2 different sources of dead animals. The specific diet item seagrass Halodule wrightii was ingested significantly more often by stranded animals (Table 1). In general, $H$. wrightii (total FV: $42.9 \%$ ) was the most ingested food resource, followed by 6 algal genera (total FV: $18.9 \%$ ), among them especially Ulva spp. (total FV: $6.7 \%$ ) and mangrove propagules (Avicennia shaueriana, total FV: 10.1\%; Table 2). Food contents were found in 63 oesophagi; in 4 of these, high quantities of food were detected (between 70 and $150 \mathrm{ml}$ ).

The feeding index showed a variation in food resource ingestion related to seasonal availability (Table 2). Juvenile turtles focused their diet on seagrass, showing higher values in the early rainy (FI: 97.3) and early dry season (FI: 65.6). Ulva spp. was the second most ingested food resource, with high values in the late dry season (FI: 23.9), and Avicennia shaueriana was the third most utilised food resource, also showing the highest values in the late dry (FI: 11.5) and 
Table 1. Chelonia mydas. Kruskal-Wallis test results for the 2 groups of turtles (stranded and from fishing activities) and total and specific diet and anthropogenic debris. ns: nonsignificant; ${ }^{*} \mathrm{p}<0.05{ }_{i}{ }^{* *} \mathrm{p}<0.01$

\begin{tabular}{|lccc|}
\hline \multirow{2}{*}{ Variables } & \multicolumn{3}{c|}{ Kruskal-Wallis test } \\
& $\mathrm{df}$ & $H$ & $\mathrm{p}$ \\
\hline Total diet & 1 & 0.67 & $\mathrm{~ns}$ \\
Halodule wrightii & 1 & 5.17 & ${ }^{*}$ \\
Avicennia shaueriana & 1 & 0.46 & $\mathrm{~ns}$ \\
Ulva spp. & 1 & 0.03 & $\mathrm{~ns}$ \\
Gracilaria spp. & 1 & 0.92 & $\mathrm{~ns}$ \\
Total debris & 1 & 10.17 & ${ }^{* *}$ \\
Plastic bag & 1 & 11.53 & ${ }^{* *}$ \\
Hard plastic & 1 & 11.79 & ${ }^{* *}$ \\
Rubber & 1 & 0.02 & $\mathrm{~ns}$ \\
Nylon & 1 & 7.43 & ${ }^{* *}$ \\
Polystyrene & 1 & 8.08 & ${ }^{* *}$ \\
\hline
\end{tabular}

late rainy season (FI: 12; Table 2, Fig. 2). Four animals that had no gut contents were collected in the early dry (1 animal) and late dry ( 3 animals) seasons.

Anthropogenic debris had a high frequency of occurrence in turtle guts $(69.7 \%)$, especially in the intestine (Table 2). A total of 3737 inorganic items, weighing $151.8 \mathrm{~g}$ and occupying $935.2 \mathrm{ml}$, were observed, corresponding to $16.1 \%$ of the total frequency by volume of the total matter ingested. When considering the different source of turtles (stranded versus caught in fishing gear), total anthropogenic debris and specific types of debris (plastic bags, hard plastic, nylon and polystyrene) were ingested significantly more often by animals caught in fishing gear (Table 1). In general, plastic bags $(44.7 \%)$ were ingested significantly more often than other types of debris (Table 3). Hard plastic $(38.5 \%)$, nylon $(7.73 \%)$, polystyrene $(5.1 \%)$ and rubber $(1.1 \%)$ were found in lower amounts (Fig. 3). No significant differences were detected among colours of anthropogenic debris. The size categories $0-1$ and $1.1-5 \mathrm{~cm}^{2}$ were ingested significantly more often. Each individual turtle had ingested between 0.2 and $113 \mathrm{ml}$ and up to 781 items. Even though no significant differences were detected among seasons and areas, the FI showed that anthropogenic debris was more prevalent in the late rainy season, considering items from the oesophagus, stomach and intestine together (FI: 60.3; Tables 2 \& 3, Fig. 3).

\section{Food resource availability}

Seagrass meadows consisting mainly of Halodule wrightii covered ca. $10.2 \mathrm{~km}^{2}$ in the lower estuary (Fig. 1), the largest area observed in the Paranaguá

Table 3. Chelonia mydas. Kruskal-Wallis test results for number of anthropogenic debris items ingested and seasons, areas, type, colour and size of debris. ns: non-significant; ${ }^{*} \mathrm{p}<0.05$

\begin{tabular}{|lccc|}
\hline \multirow{2}{*}{ Variables } & \multicolumn{3}{c|}{ Kruskal-Wallis test } \\
& $\mathrm{df}$ & $H$ & $\mathrm{p}$ \\
\hline Season & 3 & 6.43 & $\mathrm{~ns}$ \\
Area & 4 & 7.95 & $\mathrm{~ns}$ \\
Type of debris & 4 & 8.33 & ${ }^{*}$ \\
Colour of debris & 2 & 1.68 & $\mathrm{~ns}$ \\
Size of debris & 3 & 8.64 & $*$ \\
\hline
\end{tabular}

Table 2. Chelonia mydas. Total volume, volume of oesophagus (Oes) + stomach (St) and volume of the intestine. Frequency of volume (FV) represented by total volume values; frequency of occurrence (FO) is the number of digestive tracts in which the item was found. The feeding index (FI) is presented using the local rainfall patterns as seasons of the year. Gaps indicate that the food item was not ingested

\begin{tabular}{|c|c|c|c|c|c|c|c|c|c|}
\hline \multirow[t]{3}{*}{ Food items } & \multicolumn{3}{|c|}{ Digestive tract portions (ml) } & \multirow{2}{*}{\multicolumn{2}{|c|}{ Frequency \% }} & \multicolumn{4}{|c|}{ FI/season } \\
\hline & \multirow[t]{2}{*}{ Total } & \multirow[t]{2}{*}{$\mathrm{Oes}+\mathrm{St}$} & \multirow[t]{2}{*}{ Intestine } & & & \multicolumn{2}{|c|}{ Rainy } & \multicolumn{2}{|c|}{ Dry } \\
\hline & & & & FV & $\mathrm{FO}$ & Early & Late & Early & Late \\
\hline Halodule wrightii & 2490.60 & 2490.60 & & 42.9 & 46.1 & 97.3 & 1.7 & 65.6 & 5.3 \\
\hline Avicennia shaueriana & 585.8 & 325.1 & 260.7 & 10.1 & 43.4 & & 12 & 7.6 & 11.5 \\
\hline Gracilaria spp. & 243.8 & 243.8 & & 4.2 & 18.4 & 0.3 & 10.5 & 7.9 & 3.6 \\
\hline Gigarttina sp. & 108.7 & 108.7 & & 1.9 & 9.2 & & & & 6.7 \\
\hline Hypnea sp. & 280.3 & 280.3 & & 4.8 & 3.9 & 1.3 & 3.3 & & 11.8 \\
\hline Ulva spp. & 385.7 & 363.2 & 22.5 & 6.7 & 26.3 & 0.1 & 3.6 & 1.1 & 23.9 \\
\hline Unidentified green algae & 5.1 & 5.1 & & 0.1 & 2.6 & 0.1 & 0.5 & 0.1 & \\
\hline Sargassum spp. & 68.9 & 35.8 & 33.1 & 1.2 & 5.3 & & 4.2 & 0.2 & 0.7 \\
\hline Vegetation fragments & 345.5 & 124.5 & 221 & 6 & 10.5 & & 0.9 & 0.6 & 8.1 \\
\hline Animal prey & 139.2 & 139.2 & & 2.4 & 7.9 & & 0.7 & 0.2 & 6.6 \\
\hline Shell fragments & 207.2 & 38.7 & 168.5 & 3.6 & 26.3 & 0.2 & 2.2 & 0.8 & 0.7 \\
\hline Debris & 935.2 & 118.9 & 816.3 & 16.1 & 69.7 & 0.8 & 60.3 & 15.9 & 21.2 \\
\hline Total & 5795.9 & 4273.8 & 1522.1 & & & & & & \\
\hline No. of turtles analysed & 76 & & & & & 12 & 12 & 28 & 24 \\
\hline
\end{tabular}




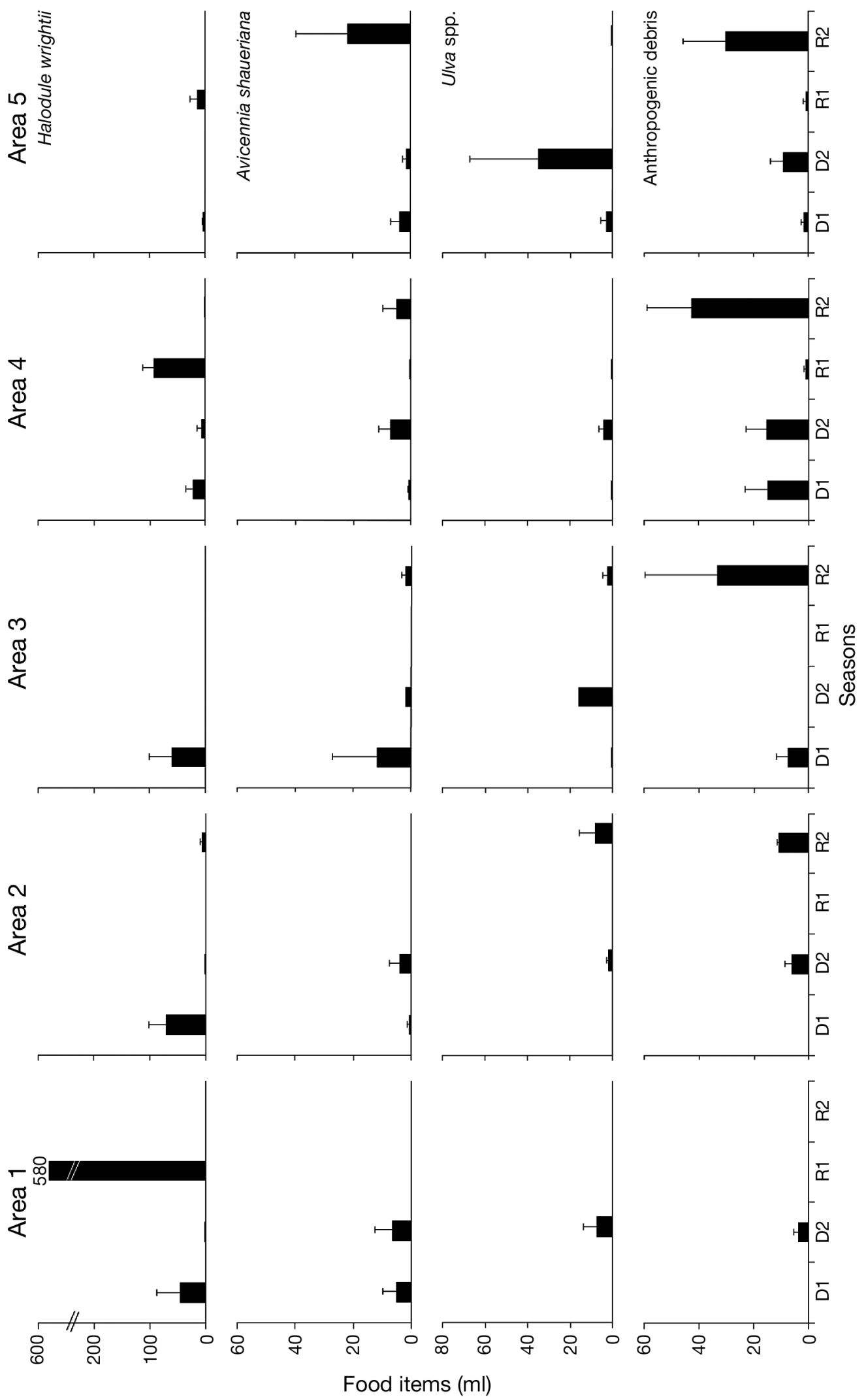

Fig. 2. Chelonia mydas. Volume (mean $+\mathrm{SE}$ ) of the 4 most important food items found in the oesophagus and stomach of turtles, presented for each of 5 stranding areas (see Fig. 1) and season of stranding (D1: early dry, D2: late dry, R1: early rainy and R2: late rainy season). Anthropogenic debris items were collected from the oesophagus, stomach and intestines 
Estuary. The meadows were more abundant in the early dry and rainy seasons, with low quantities in the late dry and rainy seasons. Ulva spp. was found in abundance on rocky shores and other hard structures such as breakwaters and harbour walls year round, with no apparent seasonality. The algal area was estimated at $99.7 \mathrm{~km}^{2}$. Mangrove forests (Laguncularia racemosa, Rhizophora mangle, Avicennia shaueriana) lined the shores of the entire estuary (160.8 $\mathrm{km}^{2}$; Table 4). The propagules of $A$. shaueriana have a fluorescence and dispersion phase that peaks in the late rainy season (R2). Therefore, when the propagules do not fix to the substrate, they are carried away by tides and can remain available for months in the water, until decomposition.

\section{Food selection}

Based on the 10 most commonly ingested items, the cluster analysis defined 2 main groups (Fig. 4). The first group was divided into 2 sub-groups: Sub-group A comprised 31 turtles stranded in the lower estuary and adjacent areas (Areas 2, 3, 4, 5 in Fig. 1), principally during the dry season. The gut contents of turtles in this sub-group contained mainly hard plastic, polystyrene, plastic bags, shell fragments, propagules of Avicennia shaueriana and Ulva spp. Sub-group B comprised 22 animals stranded in areas located in the middle, lower estuary and adjacent areas (Areas 1, 3, 4, 5 in Fig. 1) during the late dry and late rainy seasons; these animals had ingested Gracilaria and anthropogenic debris (e.g. rubber and nylon). Group II con-
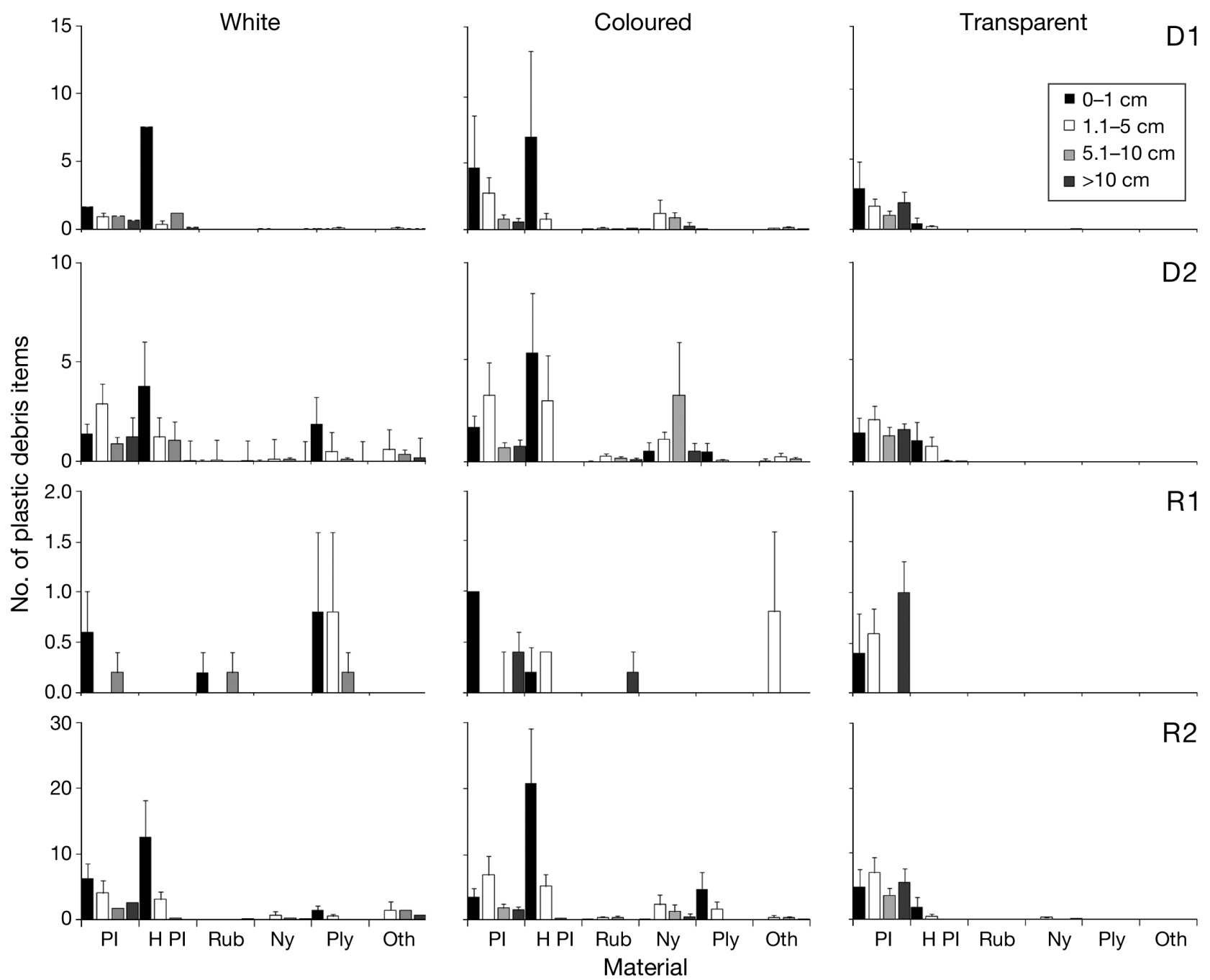

Fig. 3. Chelonia mydas. Number (mean + SE) of anthropogenic debris items ingested by green turtles, classified by material (Pl: plastic, H Pl: hard plastic, Rub: rubber, Ny: nylon, Ply: polystyrene, Oth: Other), size of debris in each colour (white, coloured and transparent) and seasonality (D1: early dry, D2: late dry, R1: early rainy and R2: late rainy season) 
Table 4. Paranaguá Estuary. Estimated coverage, distribution, and seasonality of the 3 main food resources that were identified in the gut contents of green turtles collected locally, in the early dry (D1), late dry (D2), early rainy (R1) and late rainy (R2) seasons

\begin{tabular}{|c|c|c|c|}
\hline Characteristic & $\begin{array}{l}\text { Halodule wrightii } \\
\text { meadows }\end{array}$ & $\begin{array}{l}\text { Mangrove } \\
\text { forests }\end{array}$ & $\begin{array}{c}\text { Algae } \\
\text { (Ulva spp.) }\end{array}$ \\
\hline Area of coverage $\left(\mathrm{km}^{2}\right)$ & 10.2 & 160.8 & 99.7 \\
\hline Area of occurrence & Estuarine & Estuarine & Coastal, estuarine \\
\hline Seasonality & R1, D1 & R1, R2, D1，D2 & R1, R2, D1, D2 \\
\hline
\end{tabular}

and for anthropogenic debris in the late rainy season. Ingestion of animals was rare, suggesting that this kind of ingestion may be accidental.

Green turtles found stranded and collected from fishermen were generally found to have similar diets. However, Halodule wrightii was more frequently consumed by animals found stranded, whereas anthropogenic debris was more frequently present in animals collected by fishermen, sug-

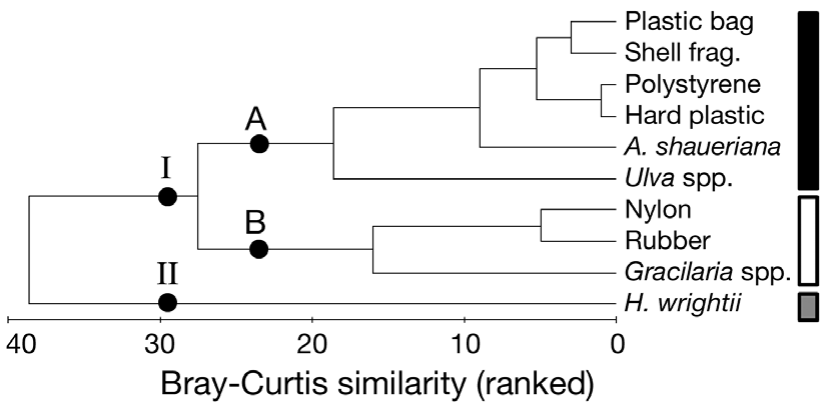

Fig. 4. Chelonia mydas. Cluster dendrogram of diet of green turtles. Samples were clustered by complete linkage of ranked Bray-Curtis similarity index based on log $(x+1)$ transformation, in the early dry (D1), late dry (D2), early rainy (R1) and late rainy (R2) seasons, in each area of the Paranaguá Estuary. Samples were divided into 2 main groups (I, II), and Group I was further subdivided into 2 sub-groups $(\mathrm{A}, \mathrm{B})$. A. shaueriana: Avicennia shaueriana; H. wrightii: Halodule wrightii

sisted of 23 animals which had ingested Halodule wrightii during the early dry and early rainy seasons, in the lower estuary (Areas 1, 2, 3 in Fig. 1).

\section{DISCUSSION}

The diet of juvenile green turtles in the Paranaguá Estuary was considered primarily herbivorous. Halodule wrightii presented the highest values by volume and importance. This result was similar to studies carried out in Nicaragua (Mortimer 1981) and Australia (Fuentes et al. 2006, Arthur et al. 2009). Food items such as mangrove propagules (Avicennia shaueriana) and the green alga Ulva spp. also presented high FI values. Changes in diet composition by season were probably due to seasonal changes in resource availability. $H$. wrightii ingestion showed evident seasonality, with higher frequency of ingestion in the early rainy and dry seasons. In other seasons, there was a moderate ingestion of $A$. shaueriana (late dry and rainy seasons). In the case of Ulva spp., maximum frequencies of ingestion were recorded in the late dry season, gesting that the latter group might have been in poor health, perhaps comparable to that of stranded turtles.

The method used for gut content analysis is only suitable for reasonably fresh carcasses such as those examined in this study. Although there is no means of determining with an acceptable degree of certainty whether these animals had died within the estuary or on adjacent beaches, the fresh state of the carcasses indicates that the animals had died recently $(\sim 1 \mathrm{~d})$, and thus likely were not transported far distances by currents. This suggests that they had recently fed and died within the influence of the Paranaguá Estuary.

Food resources were estimated, and Halodule wrightii showed a seasonal variation in distribution and abundance, as it was found in higher quantities in the early dry and early rainy seasons. At this time of the year, water transparency is at its maximum due to the long dry season facilitating light penetration and favouring blooming. The peak of coverage is during warmer months, and depends on water transparency. Studies confirm that this species is sensitive to physical modifications in the environment, and because of the low rates of reproduction, the populations are isolated in patches limited to sheltered and shallow habitats within the Paranaguá Estuary (Creed 1999). Our results, as well as the findings reported by Sordo (2008), corroborate this idea. Avicennia shaueriana and Ulva spp. were registered in high abundances throughout the year, with no strong influence of seasonality.

Halodule wrightii was consumed in comparatively larger amounts during the early dry and rainy season than during the peak coverage period in the late dry season. Although propagules of Avicennia shaueriana and algae, especially Ulva spp., are always available in the Paranaguá Estuary, they were ingested more frequently in the late rainy and late dry seasons, respectively. H. wrightii meadows occur as small patches within the estuary, and their southwestern Atlantic limit of occurrence was reported as being no farther south than the studied area (Creed 1999). The turtles that had ingested a specific diet such as $H$. wrightii had found this resource in the middle and lower areas of 
the Paranaguá Estuary (e.g. Areas 1, 2 and 3 in Fig. 1). A few areas in the northeast portion of the Paranaguá Estuary that were not surveyed in this study seem to have some seagrass patches, as confirmed by fishermen (Fig. 1), indicating that the main area of seagrass coverage may be larger. Algae are found in different environments and attached to hard substrates inside the estuary and in adjacent areas, whereas A. shaueriana propagules are carried out from mangrove forests by currents and can be available at the water surface for a long period. These materials (including anthropogenic debris) are found in converging water masses following the tides. These food resources could probably be found more easily than $H$. wrightii due to their distribution at the water surface as a result of currents.

No food was found in the gut contents of 4 turtles collected during the dry season ( 1 in the early dry and 3 in the late dry season). According to the FI, this season was characterised by a generally low ingestion of food items, including Ulva spp., Avicennia shaueriana and anthropogenic debris. This fact may be due to the lower availability of the most ingested resource (Halodule wrightii) than in other seasons.

Preferences of juvenile green turtles were previously analysed in studies which reported a selected diet of seagrass (Fuentes et al. 2006) and algae (BrandGardner et al. 1999) in Australia, and algae in Mexico (López-Mendilaharsu et al. 2008). Green turtles analysed in the present study used 12 varieties of food resources, 3 of them with greater intensity. This is relatively low compared with studies in Australia, (Fuentes et al. 2006), Central and South America (Ferreira 1968, Bugoni et al. 2003, Carrión-Cortez et al. 2010) and Baja California (Seminoff et al. 2002; Table 5). Therefore, our study reinforces the assumption that green turtle foraging habits are connected to the availability and abundance of food resources (Forbes 1996).
Mangrove items (leaves, propagules) have been found to be common in green turtle diets (Pendoley \& Fitzpatrick 1999, Limpus \& Limpus 2000, LópezMendilaharsu et al. 2005, Amorocho \& Reina 2007, Arthur et al. 2009, Carrión-Cortez et al. 2010). In our study, mangrove propagules were found 'intact' in 33 out of 76 faecal samples analysed, a similar rate to that for Ulva spp. and Sargassum spp., indicating low digestibility. Other studies observed the same behaviour in relation to food items such as the algae $S$. horridum (López-Mendilaharsu et al. 2005) and Sargassum spp. (Seminoff et al. 2002). Although changes in diet may be determined by seasonal variations, the low digestibility of some food items may indicate that diet is also influenced by food quality. Green turtles may eat mangrove propagules, leaves and algae when there are no better quality resources available at the foraging grounds. Bjorndal (1980) confirmed that digestion of items such as algae and mangrove requires radical changes in gut microflora. When animals (turtles and dugongs) that feed primarily on seagrass change to algae and mangrove materials, these items will have low digestibility, passing through the intestine apparently unaltered.

Direct evidence of juvenile green turtles feeding in the lower estuary contributed to the findings of this study. On 2 occasions during scuba diving in the Paranaguá Estuary, we observed juveniles foraging on the sea bottom at a depth of $6 \mathrm{~m}$, probably in the seagrass meadows, when the visibility was approximately $4 \mathrm{~m}$. Local fishermen reported to have similar sightings when they dive at the lower estuary sites and adjacent coastal areas (Areas 2, 3, 4, 5 in Fig. 1). They observe juveniles and adults, indicating that the area is used by both life stages. Moreover, the majority of turtles showed signs of recent foraging (food contents in the oesophagus), confirming the fact that the Paranaguá Estuary is a foraging ground for juvenile green turtles as only juveniles of the species

Table 5. Chelonia mydas. Summary of studies of green turtle diets, comparing life stages, total number of ingested items and number of species of each group. Anthropogenic debris was summarised under the term 'plastic debris'. na: not available

\begin{tabular}{|c|c|c|c|c|c|c|c|c|}
\hline \multirow[t]{2}{*}{ Area } & \multirow{2}{*}{$\begin{array}{l}\text { Life } \\
\text { stage }\end{array}$} & \multirow{2}{*}{$\begin{array}{l}\text { Total } \\
\text { ingested } \\
\text { items }\end{array}$} & \multirow[b]{2}{*}{$\begin{array}{l}\text { Seagrass } \\
\text { species }\end{array}$} & \multirow[b]{2}{*}{$\begin{array}{l}\text { Algal } \\
\text { species }\end{array}$} & \multirow{2}{*}{$\begin{array}{l}\text { Food type - } \\
\text { Mangrove } \\
\text { species }\end{array}$} & \multirow[b]{2}{*}{$\begin{array}{l}\text { Animal } \\
\text { species }\end{array}$} & \multirow[b]{2}{*}{$\begin{array}{l}\text { Plastic } \\
\text { debris }\end{array}$} & \multirow{2}{*}{ Source } \\
\hline & & & & & & & & \\
\hline Australia & Adult & 73 & 3 & 61 & na & 7 & na & Garnett et al. (1985) \\
\hline Australia & Juvenile & 24 & 5 & 16 & na & 3 & na & Fuentes et al. (2006) \\
\hline Gulf of California & $\begin{array}{l}\text { Juvenile } \\
\text { and adult }\end{array}$ & 42 & na & 17 & na & 24 & 1 & Seminoff et al. (2002) \\
\hline Nicaragua & $\begin{array}{l}\text { Juvenile } \\
\text { and adult }\end{array}$ & 30 & 4 & 23 & na & 3 & na & Mortimer (1981) \\
\hline Galapagos & $\begin{array}{l}\text { Juvenile } \\
\text { and adult }\end{array}$ & 30 & na & 22 & 1 & 6 & na & $\begin{array}{l}\text { Carrión-Cortez et al. } \\
\text { (2010) }\end{array}$ \\
\hline South Brazil & Juvenile & 21 & 1 & 2 & na & 17 & 8 & Bugoni et al. (2003) \\
\hline South Brazil & Juvenile & 12 & 1 & 6 & 1 & 1 & 6 & Present study \\
\hline
\end{tabular}


were stranded in the area. There are no records of other seagrass meadows in a range of $200 \mathrm{~km}$.

Sea turtle strandings were more common in the early and late dry seasons $(70 \%)$. At this time of year, strong winds blow from the south and southeast, pushing carcasses to the beaches and into the estuary. Fishermen and a previous study (Guebert et al. 2005) confirmed that fishing activities are the major threat to green turtles in the Paranaguá Estuary and adjacent areas. Probably not only the 9 animals analysed in this study died due to interactions with fishing: most of the animals found stranded did not present any signs of illness, and the carcasses were robust, suggesting that they were foraging normally. Fishermen reported that in the dry season, fishing activities in the estuary and adjacent areas are dedicated to target species (flat fish) captured with large mesh gillnets that drift in the water for $24 \mathrm{~h}$. Juvenile green turtles are easily entangled and when found are already dead. During the rainy season, especially the early rainy season, tourism is the main economic activity in the area, and the public services clean the beaches every day. Therefore, turtles that stranded in the rainy season were probably removed before we could detect and collect them during our weekly monitoring efforts.

The occurrence of plastic debris (especially plastic bags and hard plastic) in green turtle digestive tracts is related to the prevalence of this type of pollution in riverine, estuarine and coastal environments, increasing the possibility of interactions between plastics and marine organisms (Gregory 2009). The highest ingestion of anthropogenic debris was observed in the late rainy season, when the most frequently ingested resource (Halodule wrightii) was not available and the other resources were consumed in low quantities. On the other hand, anthropogenic debris could have been ingested in the late dry and early rainy seasons, considering that it moves at a slower pace than food in the digestive tract and may remain there for up to $6 \mathrm{mo}$ (Schulman \& Lutz 1995). Our results show the source of anthropogenic debris to be land based (urban areas), with debris washed down rivers and creeks or coming from beach users. Fishing and shipping are well-known sources of anthropogenic debris to coastal areas (Gregory 2009, Ryan et al. 2009), and the Paranaguá Estuary is no exception according to our data.

Ingestion of anthropogenic debris can cause physical damage such as inflammations, gut obstructions and difficulty passing faecal material (McCauley \& Bjorndal 1999). These afflictions can lead to floating syndrome and, consequently, green turtles become more vulnerable to vessel collisions and entanglement in gillnets, causing injuries or death (Bjorndal et al. 1994, Hazel et al. 2007; Fig. 5). During the present study, 4 animals were collected with an especially high amount of plastic debris in their gut contents. In these particular cases, we suggest that the ingestion of plastics may have been the cause of death. Different types of problems were identified in green turtles analysed in this study related to anthropogenic debris ingestion, such as internal and external wounds in the intestine, ulcer-

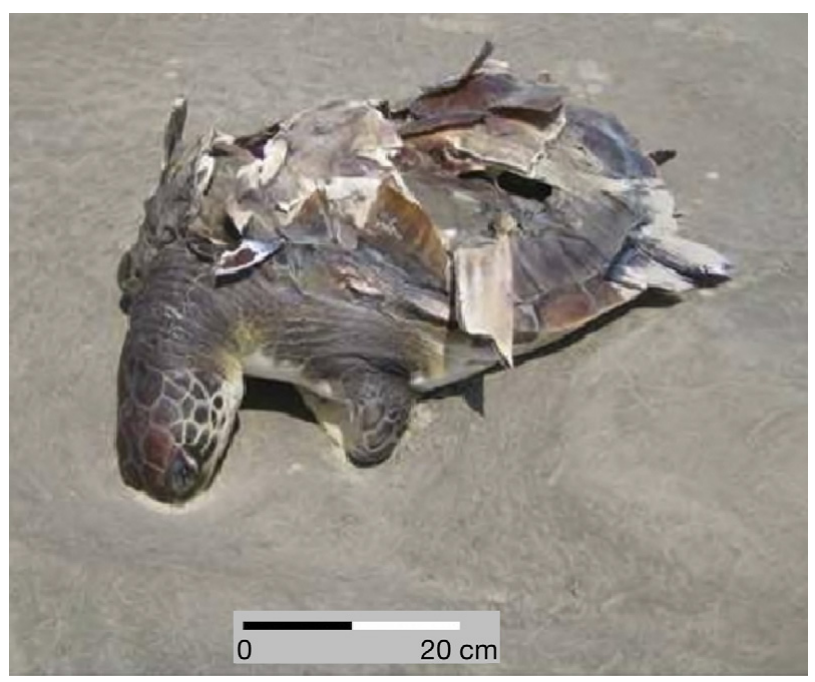

Fig. 5. Chelonia mydas. Dead green turtle, probably from a boat-strike in the Paranaguá Estuary

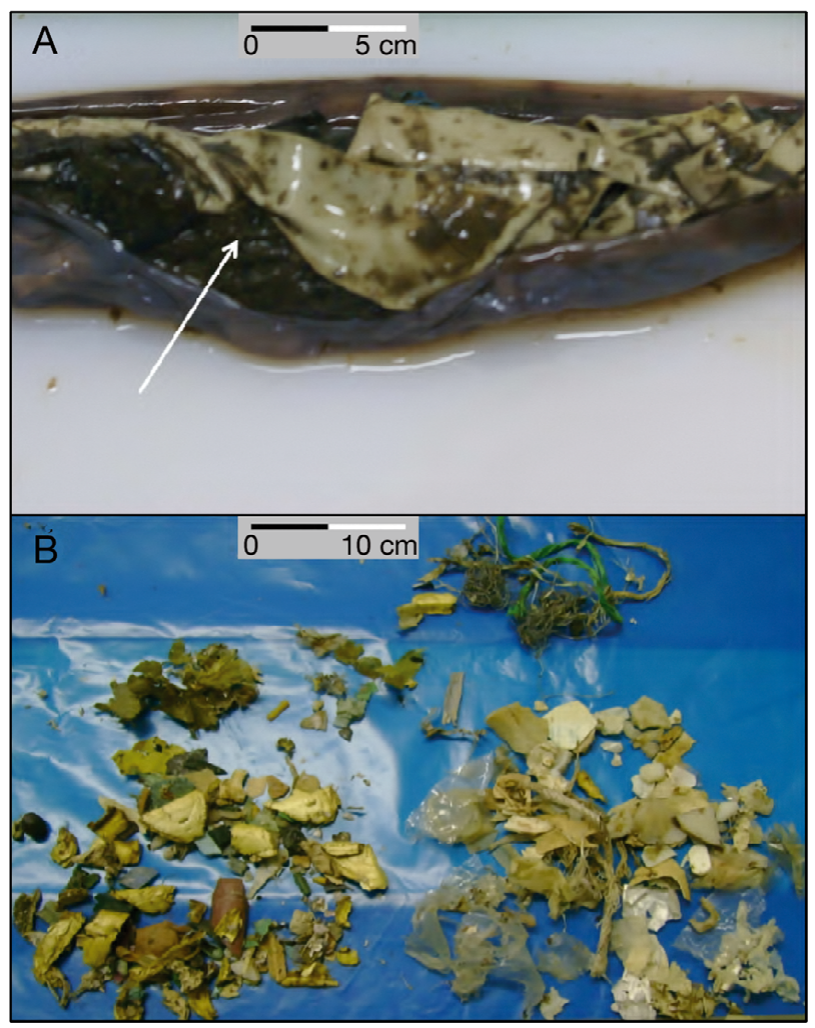

Fig. 6. Chelonia mydas. (A) Piece of hard plastic in the digestive tract and (B) plastic debris found in one intestine of a green turtle from the Paranaguá Estuary 
ating sores, blockage of the digestive tract (faecalomas) and compacted gut (Fig. 6). Moreover, in contact with the animals' digestive tracts, plastics release chemical contaminants directly to the animal without magnification along the food chain (Islam \& Tanaka 2004, Teuten et al. 2007, 2009).

\section{CONCLUSIONS}

Similar diets among turtles that ingested estuarinerelated food resources (e.g. Halodule wrightii) show that green turtles look for sheltered habitats to forage, reinforcing the importance of protection of positively identified feeding grounds in these ecosystems. Adequate management and conservation strategies of the main estuary and habitats are important for guaranteeing the survival of borderline populations and therefore genetic variability. Considering that extensive relationships between animals from southern Brazil and other Atlantic foraging and nesting areas occur, these must depend on healthy populations of green turtles.

The other food resources used by juvenile green turtles in the Paranaguá Estuary also need conservation actions in order to guarantee diet diversity for these animals and thus also maintain habitat diversity in and around the ecosystem. Projects in ecology and conservation, as well as green turtle home range studies and a more precise and complete delimitation of the occurrence of seagrass meadows, are necessary, and should consider area and time. The occurrence of populations of Chelonia mydas juveniles highlights the importance of the Paranaguá Estuary as a developmental habitat in the southwestern Atlantic Ocean. The ecological role of estuarine and adjacent habitats for marine turtles, especially C. mydas, still needs to be further understood. Conservation efforts and management of the estuary and its protected areas are urgently needed to preserve habitats that also provide food and shelter for other groups such as fish and marine mammals.

Initiatives to quantify and qualify the amounts of plastic debris, its sources and behaviour in the estuary are necessary. These could be the basis for cleaning and educational projects to promote changes in practices aiming to reduce plastic littering. This global problem requires educational awareness at all economic and social levels. Specially designed campaigns in schools, private businesses (ports, fishing and tourism), beaches and urban areas must join with these initiatives and with law enforcement. The infrastructures to collect, process, recycle and deposit solid wastes should be adequate to avoid pollution and guarantee the quality of the services, the responsibility of all stakeholders.
Fishermen have always been and will remain an important group of stakeholders in the Paranaguá Estuary area. Some restriction to fishing practices that interfere with turtles should be closely monitored in areas identified as feeding grounds. Reducing contact and mortality of green turtles in fishing nets would be one of the possible contributions of fishermen to the conservation of this species. Other initiatives from this group aimed at estuarine conservation would foster not only turtle habitat conservation but also the sustainability of their own activities.

Acknowledgements. We thank the post-graduate programme in Zoology of the Federal University of Paraná, Conselho Nacional de Desenvolvimento Científico e TecnológicoCNPq (Proc. 132682/2006-0). Financial and logistical support was provided by Project Aware (PADI Foundation), Idea Wild and Centro de Estudos do Mar (UFPR). M.B. received a research fellowship from CNPq. We thank L. N. Sordo for collaborating in the seagrass discussion and for the dives in the Paranaguá Estuary. We also thank the anonymous reviewers for their important contributions to earlier versions of this manuscript.

\section{LITERATURE CITED}

Amorocho DF, Reina RD (2007) Feeding ecology of the East Pacific sea turtle Chelonia mydas agassizii at Gorgona National Park, Colombia. Endang Species Res 3:43-51

Andriguetto-Filho JM, Krul R, Feitosa S (2009) Analysis of natural and social dynamics of fishery production systems in Paraná, Brazil: implications for management and sustainability. J Appl Ichthyol 25:277-286

- Arthur KE, Balazs GH (2008) A comparison of immature green turtle (Chelonia mydas) diets among seven sites in the main Hawaiian Islands. Pac Sci 62:205-217

Arthur KE, McMahon KM, Limpus CJ, Dennison WC (2009) Feeding ecology of green turtles (Chelonia mydas) from Shoalwater Bay, Australia. Mar Turtle Newsl 123:6-11

Barletta M, Amaral CS, Corrêa MFM, Guebert FM, Dantas DV, Lorenzi L, Saint-Paul U (2008) Factors affecting seasonal variations in demersal fish assemblages at an ecocline in a tropical-subtropical estuary. J Fish Biol 73: $1314-1336$

Barletta M, Jaureguizar AJ, Baigun C, Fontoura NF and others (2010) Fish and aquatic habitat conservation in South America: a continental overview with emphasis on neotropical systems. J Fish Biol 76:2118-2176

Bjorndal KA (1980) Nutrition and grazing behavior of the green turtle Chelonia mydas. Mar Biol 56:147-154

Bjorndal KA (1997) Foraging ecology and nutrition of the sea turtles. In: Lutz PL, Musick JA (eds) The biology of sea turtles, Vol 1. CRC Press, Boca Raton, FL, p 199-232

Bjorndal KA, Bolten AB, Lageux CJ (1994) Ingestion of marine debris by juvenile sea turtles in coastal Florida habitats. Mar Pollut Bull 28:154-158

Bolten AB (2003) Variation in sea turtle life history patterns: neritic vs. oceanic development stages. In: Lutz PL, Musick JA, Wyneken J (eds) The biology of sea turtles, Vol II. CRC Press, Washington, DC, p 243-258

Bondioli ACV, Naro-Maciel E, Toledo LFA (2009) Estrutura populacional de tartaruga-verde (Chelonia mydas) da região de Cananéia, São Paulo. IV Jornada de Investi- 
gación e Conservación de Tortugas Marinas em El Atlántico Sur Occidental. ASO, Mar Del Plata

Brand-Gardner SJ, Lanyon JM, Limpus CJ (1999) Diet selection by immature green turtles, Chelonia mydas, in subtropical Moreton Bay, south-east Queensland. Aust J Zool 47:181-191

Bugoni L, Krause L, Petry MV (2003) Diet of sea turtles in southern Brazil. Chelonian Conserv Biol 4:685-688

Carrión-Cortez JA, Zárate P, Seminoff AJ (2010) Feeding ecology of the green sea turtle (Chelonia mydas) in the Galapagos Islands. J Mar Biol Assoc UK 90:1005-1013

Clarke KR, Warwick RM (1994) Change in communities: an approach to statistical analysis and interpretation. Natural Environment Research Council, Plymouth

Clarke PJ (1993) Dispersal of grey mangrove (Avicennia marina var. australasica) propagules in south-eastern Australia. Aquat Bot 45:195-204

Creed JC (1999) Distribution, seasonal abundance and shoot size of the seagrass Halodule wrightii near its southern limit at Rio de Janeiro State, Brazil. Aquat Bot 65:47-58

Dahdouh-Guebas F, Coppejans E, Van Speybroeck D (1999) Remote sensing and zonation of seagrasses and algae along the Kenyan coast. Hydrobiologia 400:63-73

de Oliveira EC, Pirani JR, Giulietti AM (1983) The Brazilian seagrasses. Aquat Bot 16:251-267

Ferreira B, Garcia M, Jupp BP, Al-Kiyumi A (2006) Diet of green turtle (Chelonia mydas) at Ra's Al Hadd, Sultanate of Oman. Chelonian Conserv Biol 5:141-146

Ferreira MM (1968) Sobre a alimentação da Aruanã, Chelonia mydas (Linnaeus), ao longo da costa do Estado do Ceará. Arq Estaç Biol Mar Univ Fed Ceará 8:83-86

Forbes GA (1996) Diet sampling and feeding ecology of green turtles (Chelonia mydas) in an algal-based coral reef community. PhD thesis, James Cook University, Townsville

Forbes GA (1999) Diet sampling and diet component analysis. In: Eckert KL, Bjorndal KA, Abreu-Grobois FA, Donnely $M$ (eds) Research and management techniques for the conservation of sea turtles. IUCN/SSC Marine Turtle Specialist Group Publication, Washington, DC, p 144-149

Fuentes MMPB, Lawler I, Gyuris E (2006) Dietary preferences of juvenile green turtles (Chelonia mydas) on a tropical reef flat. Wildl Res 33:671-678

Garnett ST, Price IR, Scott FJ (1985) The diet of the green turtle, Chelonia mydas (L.), in Torres Strait. Aust Wildl Res 12:103-112

Godley BJ, Lima EHSM, Akesson S, Broderick AC and others (2003) Movement patterns of green turtles in Brazilian coastal waters described by satellite tracking and flipper tagging. Mar Ecol Prog Ser 253:279-288

Gregory MR (2009) Environmental implications of plastic debris in marine settings-entanglement, ingestion, smothering, hangers-on, hitch-hiking and alien invasions. Phil Trans R Soc Lond B Biol Sci 364:2013-2025

Guebert FM, Santos HF, Rodrigues JPB, Monteiro-Filho ELA (2005) Impactos antrópicos sobre as populações de tartarugas marinhas no litoral do Estado do Paraná. Monteiro DS, Sales G, Estima SC, Bugoni L (eds) II Jornada de Conservação e Pesquisas de Tartarugas Marinhas no Atlântico Sul Ocidental, ASO, Rio Grande

> Hazel J, Lawler IR, Marsh H, Robson S (2007) Vessel speed increases collision risk for the green turtle Chelonia mydas. Endang Species Res 3:105-113

> Hyslop EJ (1980) Stomach analysis - a review of methods and their application. J Fish Biol 17:411-429

> Islam MS, Tanaka M (2004) Impacts of pollution on coastal and marine ecosystems including coastal and marine fish- eries and approach for management: a review and synthesis. Mar Pollut Bull 48:624-649

IUCN (2009) The 2009 IUCN Red list of Threatened Animals. The IUCN Species Survival Commission. Available at www.iucnredlist.org

Joly AB (1967) Gêneros de algas marinhas da costa Atlântica latino americana. Universidade de São Paulo, São Paulo

Kawakami E, Vazzoler G (1980) Método gráfico e estimativa de índice alimentar aplicado no estudo de alimentação de peixes. Bol Inst Oceanogr São Paulo 29:205-207

Krug LA, Leão C, Amaral S (2007) Dinâmica espaço-temporal de manguezais no complexo Estuarino de Paranaguá e relação entre decréscimo de áreas de manguezal e dados sócio-econômicos da região urbana do município de Paranaguá- Paraná. Anais XIII Simpósio Brasileiro de Sensoriamento Remoto, INPE, Florianópolis

Limpus CJ, Limpus D (2000) Mangroves in the diet of Chelonia mydas in Queensland, Australia. Mar Turtle Newsl 89: $13-15$

> López-Castro MC, Koch V, Masriscal-Loza A, Nichols WS (2010) Long-term monitoring of black turtles Chelonia mydas at coastal foraging areas off the Baja California Peninsula. Endang Species Res 11:35-45

López-Mendilaharsu M, Gardner SC, Seminoff J, RiosmenaRodriguez R (2005) Identifying critical foraging habitats of the green turtles (Chelonia mydas) along the Pacific coast of the Baja California Peninsula, Mexico. Aquat Conserv 15:259-269

> López-Mendilaharsu M, Gardner SC, Riosmena-Rodriguez R, Seminoff J (2008) Diet selection by immature green turtles (Chelonia mydas) at Bahía Magdalena foraging ground in the Pacific Coast of the Baja California Peninsula, México. J Mar Biol Assoc UK 88:641-647

> Mancini A, Koch V (2009) Sea turtle consumption and black market trade in Baja California Sur, Mexico. Endang Species Res 7:1-10

Márquez RM (1990) Sea turtles of the world. An annotated and illustrated catalogue of sea turtle species known to date. Vol 11. FAO Fisheries Synopsis, Rome

McCauley SJ, Bjorndal KA (1999) Conservation implications of dietary dilution from debris ingestion: sublethal effects in post-hatchling loggerhead sea turtles. Conserv Biol 13: 925-929

Montague C (2008) Recovering the sand deficit from a century of dredging and jetties along Florida's Atlantic coast: a reevaluation of beach nourishment as an essential tool for ecological conservation. J Coast Res 24:899-916

> Mortimer J (1981) The feeding ecology of the west Caribbean green turtle (Chelonia mydas) in Nicaragua. Biotropica 13: 49-58

Naro-Maciel E, Becker JH, Lima EHSM, Marcovaldi MA, DeSalle R (2007) Testing dispersal hypotheses in foraging green sea turtles (Chelonia mydas) of Brazil. J Hered 98: 29-39

Noernberg MA, Lautert LFL, Araújo AD, Marone E, Angelotti R, Netto JPB, Krug LA (2004) Remote sensing and GIS integration for modeling the Paranaguá Estuarine Complex- Brazil. J Coast Res 39:1627-1631

Pendoley K, Fitzpatrick J (1999) Browsing of mangroves by green turtles in Western Australia. Mar Turtle Newsl 84:10

Pierri N, Angulo JR, Souza MC, Kim MK (2006) A ocupação e o uso do solo no litoral paranaense: condicionantes, conflitos e tendências. Desenvolvimento Meio Ambient 13: $137-167$

> Proietti MC, Lara-Ruiz P, Reisser JW, Pinto LS, Dellagostin LA, Marins LF (2009) Green turtles (Chelonia mydas) foraging at Arvoredo Island in southern Brazil: genetic char- 
acterization and mixed stock analysis through mtDNA control region haplotypes. Genet Mol Biol 32:613-618

Ryan PG, Moore CJ, Van Franeker JA, Moloney CL (2009) Monitoring the abundance of plastic debris in the marine environment. Phil Trans R Soc Lond B Biol Sci 364:1999-2012

Santos MCO, Oshima JEF, Pacífico ES, Silva E (2010) Group size and composition of Guiana dolphins (Sotalia guianensis) (Van Bénèden, 1864) in the Paranaguá Estuarine Complex, Brazil. Braz J Biol 70:111-120

Sazima I, Sazima M (1985) Aspectos de comportamento alimentar e dieta da tartaruga marinha, Chelonia mydas, no litoral norte paulista. Bol Inst Oceanogr São Paulo 32:199-203

Schulman AA, Lutz PA (1995) The effect of the plastic ingestion on lipid metabolism in the green sea turtles (Chelonia mydas). In: Richardson JI, Richardson TH (eds) Proc 12th Annu Workshop Sea Turtle Biol Conserv. NOAA Tech Memo NMFS-SEFSC-361. NOAA, Miami, FL

Seminoff J, Resendiz A, Nichols WJ (2002) Diet of the East Pacific green turtles (Chelonia mydas) in the Central Gulf of California, México. J Herpetol 36:447-453

Sessegolo GC, Lana PC (1991) Decomposition of Rhizophora mangle, Avicennia shaueriana and Laguncularia racemosa

Editorial responsibility: Jeffrey Seminoff, La Jolla, California, USA leaves in a mangrove of Paranaguá Bay (southeastern Brazil). Bot Mar 34:285-289

Sordo LN (2008) Alterações na estrutura e funcionamento de um banco de Halodule wrightii (Cymodoceacea) durante um florescimento massivo de epífitas na Baía de Paranaguá (Paraná, Brasil). MSc thesis, Federal University of Paraná, Pontal do Paraná

Storelli MM, Marcotrigiano GO (2003) Heavy metal residues in tissues of marine turtles. Mar Pollut Bull 46:397-400

Teuten EL, Rowland SJ, Galloway TS, Thompson RC (2007) Potential for plastics to transport hydrophobic contaminants. Environ Sci Technol 41:7759-7764

Teuten EL, Saquing JM, Knappe DRU, Barlaz MA and others (2009) Transport and release of chemicals from plastics to the environment and wildlife. Phil Trans R Soc Lond B Biol Sci 364:2027-2045

UNESCO (United Nations Educational, Scientific and Cultural Organization) (2010) World Heritage List 1999. Available at http://whc.unesco.org/en/stateparties/br

Wallace BP, Lewison RL, McDonald S, McDonald RK and others (2010) Global patterns of marine turtle bycatch. Conserv Lett 3:131-142

Submitted: May 25, 2010; Accepted: October 26, 2010 Proofs received from author(s): January 18, 2011 
